J. Clin. Chem. Clin. Biochem.

Vol. 14, 1976, pp. 165-171

\title{
The Reliability of a Mechanized Procedure (Perkin-Elmer C4) for the Enzymatic Determination of Uric Acid According to Kageyama
}

\author{
Von $R$. Haeckel \\ Technical assistance: Ingrid Dieterich and Iris Kasten \\ Institut für Klinische Chemie (Geschäftsführender Direktor: Prof. Dr. Dr. J. Büttner) Medizinische Hochschule \\ Hannover
}

(Received November 18, 1975/January 8,1976 )

Summary: The enzymatic determination of the uric acid concentration in urine and serum according to Kageyama ((1971), Clin. Chim. Acta 31, 421-426), which excludes the deproteinization of samples, was adapted to the C4 automatic analyzer (Perkin-Elmer). The reliability of this procedure and its correlation with an UV-method were investigated. The interaction from-sample-to-sample was considerable, but this could be reduced by the addition of Brij-35.

The recovery of uric acid added to protein-containing samples (about 96\%) was better than with the UV-method. Novaminsulfone was the only substance tested which interfered significantly.

\section{Zuverlässigkeit eines mechanisierten Verfahrens (Perkin-Elmer C4) für die enzymatische Bestimmung von Harnsäure nach Kageyama}

Zusammenfassung: Die enzymatische Bestimmung der Harnsäure Konzentration nach Kageyama ((1971), Clin. Chim. Acta 31, 421-426) wurdè an das Analysengerät C4 (Perkin-Elmer) adaptiert und deren Zuverlässigkeitskriterien untersucht. Die Verschleppung von Probe zu Probe war beträchtlich, konnte jedoch durch Zusatz von Brij reduziert werden.

Zusatzversuche von Harnsäure mit proteinhaltigen Proben ergab eine höhere Wiederfindung (um 96\%) als mit einer vergleichenden UV-Methode. Bei einer Reihe von getesteten Substanzen führte nur Novaminsulfon zu einer signifikaṇten Interfèrenz.

\section{Introduction}

Kageyama reported recently (1) a new procedure for the direct enzymatic measurement of the uric acid concen tration in urine and serum. This method uses the Hantzsch' reaction to determine formaldehyde formed from uric acid by means of the two enzymes uricase (EC 1.7.3.3) and catalase (EC 1.11.1.6). The resulting color (3,5-diacetyl-1,4-dihydrolutidine) has its absorbance maximum at $410 \mathrm{~nm}$.

This procedure appeared to be suitable for the mechanit: zation with a discrete analytical system. For this purpose we used the Perkin-Elmer C4 Automatic Analyzer, a combined-discrete system (2), since the reaction mixture is transported in single cups and then transferred into a discontinuous flow system for the photometric measurement.
In the following investigations on the reliability of the Kageyama method adjusted to the $\mathrm{C} 4$ analyzer are reported. The direct enzymatic UV-procedure of Praetorius (3) was chosen as the reference and performed manually because we did not succeed in adapting this method to the $\mathrm{C} 4$ analyzer with sufficient precision. A sample blank assay treated with a glycerol solution instead of the uricase suspension was used according to Kortüm (4).

\section{Methods and Materials}

\section{Operation of the C4 Automatic Analyzer}

The analyzer ist operated according to the instructions of PerkinElmer as shown in figure 1. The incubation time is 43 minutes at $37^{\circ}$ C. Sample batches are divided in 3 different segments as indicated in figure 2. The inter-segment $B$ can be repeated as often 


\begin{tabular}{|c|c|c|c|}
\hline \multicolumn{4}{|c|}{ Sample reagent } \\
\hline uptake-volume, $\mu l$ & 500 & & \\
\hline exhaust-volume, $\mu l$ & 200 & 2500 & \\
\hline Position & 16 & 11 & 0 \\
\hline
\end{tabular}

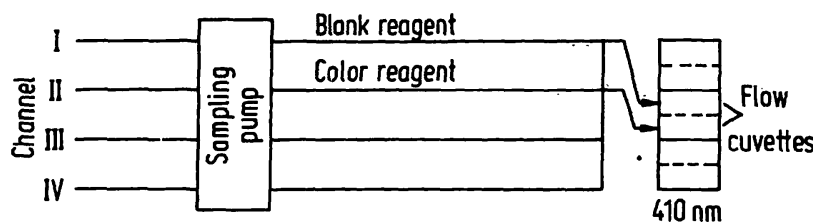

Fig. 1. Adaptation of the $\mathrm{C} 4$ Automatic Analyzer for the uric acid determination.

\footnotetext{
$(500 \mu \mathrm{l})$ using Eppendorf pipettes.

\section{Solutions}

1. Colour reagent:

$\left(\mathrm{NH}_{4}\right)_{2} \mathrm{HPO}_{4}(757 \mathrm{mmol} / 1$
$\mathrm{H}_{3} \mathrm{PO}_{4}, 85 \%(\mathrm{ca} 44 \mathrm{mmol} / \mathrm{l})$
$\mathrm{CH}_{3} \mathrm{OH}$ (ca. $\left.2.47 \mathrm{~mol} / \mathrm{l}\right)$
Acetylacetone $(19 \mathrm{mmol} / \mathrm{l})$
Catalase
Uricase
Brij-35

Bidist. $\mathrm{H}_{2} \mathrm{O}$
}

as required. The concentration factor is calculated from the first standard samples in segment $A$ and introduced into the control unit. The printed values of the standard solutions in B and C segments are corrected directly with the factor potentiometer if necessary. Blanks (bidist. $\mathrm{H}_{2} \mathrm{O}$ ) can be omitted between $3 \mathrm{~B}$ segments. Urine samples $(50 \mu \mathrm{l})$ are diluted with bidist. water

$100 \mathrm{~g}$ Merck No. 1207

$3 \mathrm{ml}$ Merck No. 573

$100 \mathrm{ml}$ Merck No. 6009

$2 \mathrm{ml}$ Merck No. 9600

$100 \mathrm{mg}$ Boehringer No. 15674

$10 \mathrm{mg}$ Boehringer No. 15074

$1 \mathrm{ml}$ Technicon No. 0214-15

2. Blank reagent: as solution (1) without uricase. Colour and blank reagent are filtered (Selecta filter No. $5951 / 2$, Schleicher and Schüll, D-3354 Dassel).

Both solutions are stable for 10 days at $4^{\circ} \mathrm{C}$ according to l.c. (1). The $\mathrm{pH}$ value of both colour and blank reagent is about 7.4 and is not adjusted to 7.0 as proposed by Kageyama (1).

3. Lithium carbonate, $135 \mathrm{mmol} / 1$
$\mathrm{Li}_{2} \mathrm{CO}_{3}$
Bidist. $\mathrm{H}_{2} \mathrm{O}$
$1.0 \mathrm{~g} \quad$ Merck No. 5671
to $100 \mathrm{ml}$

4. Uric acid stock standard, $5 \mathrm{mmol} / \mathrm{l}$. This solution is prepared according to Liddle et al. (5), chloroform is used as preservative (6).

$\begin{array}{lc}\text { Uric acid, dried } & 840.6 \mathrm{mg} \text { Merck No. } 814 \\ \text { Bidist. } \mathrm{H}_{2} \mathrm{O}\left(60-80^{\circ} \mathrm{C}\right) & 500 \mathrm{ml} \\ \left.\mathrm{Li}_{2} \mathrm{CO}_{3} 1 \mathrm{~g} / 100 \mathrm{ml}: 60-80^{\circ} \mathrm{C}\right) & 50 \mathrm{ml}\end{array}$

After the uric acid is dissolved, allow to cool to room temperature, then add

$\begin{array}{lrr}\mathrm{CHCl}_{3} & 1 \mathrm{ml} \text { Merck No. } 2431 \\ \text { Bidist. } \mathrm{H}_{2} \mathrm{O} & \text { to } 1000 \mathrm{ml}\end{array}$

This solution is stable for 1 month at $4^{\circ} \mathrm{C}$.

5. Uric acid working standard, $500 \mu \mathrm{mol} / \mathrm{l}$ :
Uric acid stock standard
$\mathrm{Li}_{2} \mathrm{CO}_{3} \mathrm{lg} / 100 \mathrm{ml}$
Bidist. $\mathrm{H}_{2} \mathrm{O}$
$10 \mathrm{ml}$
$5 \mathrm{ml}$
to $100 \mathrm{ml}$

This solution is prepared each day.

Other materials were purchased from E. Merck AG (D-6100 Darmstadt), bovine albumin (purest, dried) from Behring AG (D-3550 Marburg) and Seronorm from Dr. Molter GmbH (D-6900 Heidelberg).

The uricaquant test (Boehringer Mannheim, No. 15865) was performed according to the instructions of the manufacturer.

For the direct enzymatic determination of the uric acid concentration at $293 \mathrm{~nm}$ the Boehringer test combination No. 15986 and a Zeiss PM 4 spectrophotometer were used. All results were referred to the working standard solution (5).

The interaction from low to high concentrations $\left(Q_{1}\right)$ and from high to low concentrations $\left(Q_{2}\right)$ was determined as recently reported (7) and expressed as the percent interaction coefficient $(Q=100 \times q$; for the explanation of q see Fig. 2).

The recovery of uric acid added to various samples was calcuated from the results of the following assays:

1. $9.0 \mathrm{ml} \mathrm{Li}_{2} \mathrm{CO}_{3}$ solution $(500 \mathrm{mg} / \mathrm{l})+1.0 \mathrm{ml}$ stock standard ( $5 \mathrm{mmol} / 1$ uric acid);

$2.9 .0 \mathrm{ml}$ serum $+1.0 \mathrm{ml}$ stock standard; and

3. $9.0 \mathrm{ml}$ serum $+1.0 \mathrm{ml} \mathrm{Li}_{2} \mathrm{CO}_{3}$ solution $(500 \mathrm{mg} / \mathrm{l})$.

Statistical evaluation of precision data were performed according to l.c. (10).

\section{Results and Discussion}

Under our test conditions, the absorbance of the reaction mixture slowly increased even in the absence of uric acid (fig. 3). Precision therefore depends upon exact

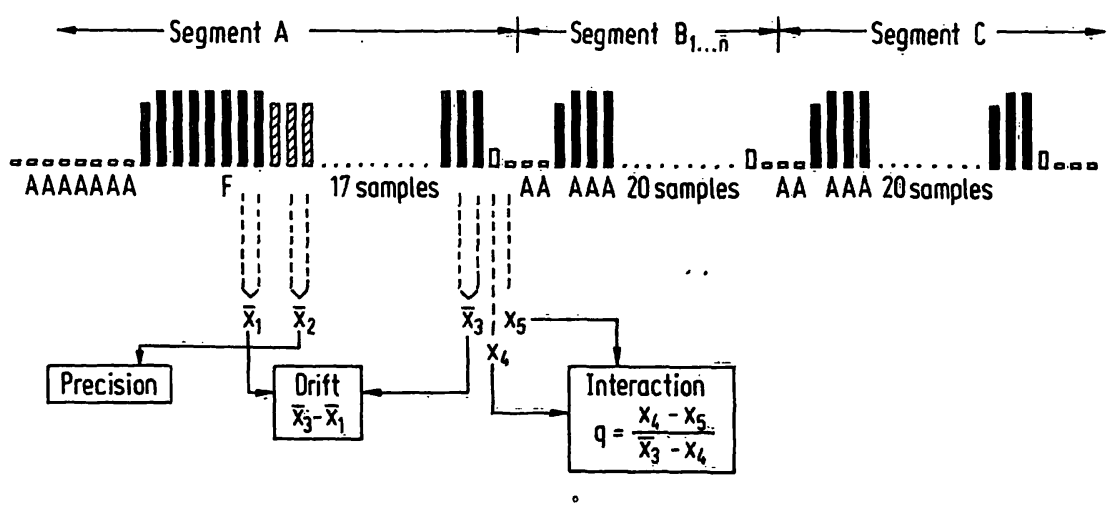

Fig. 2. Sequence of samples introduced into the $C 4$ Automatic Analyzer for the uric acid determination. A: adjustment of the corresponding potentiometer if necessary. At $F$ the concentration factor is calculated from the 4 preceeding values and introduced into the control unit. $\square$ Blank $\left(\mathrm{H}_{2} \mathrm{O}\right) \square$ Standard $\triangle$ Control. 


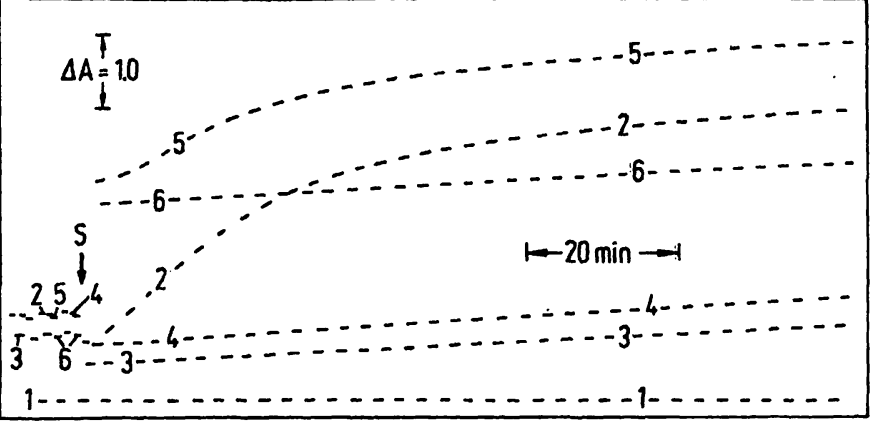

Fig. 3. The reaction rate of the uric acid determination according to Kageyama at $410 \mathrm{~mm}$ and $37^{\circ} \mathrm{C}$ (Zeiss photometer PM 4 with automatic cuvet changing device). Cuvet 1 : picric acid solution for automatic correction of $E=O$. Cuvet 2: $2500 \mu 1$ reaction solution (rs) $+200 \mu l$ uric acid solution ( $500 \mu \mathrm{mol} / \mathrm{l})$; cuvet 3: $2500 \mu \mathrm{l}$ blank solution (bs) $+200 \mu \mathrm{l}$ uric acid solution $(500 \mu \mathrm{mol} / 1)$; cuvet 4 : $2500 \mu \mathrm{l} \mathrm{rs}+200 \mu \mathrm{l}$ bidist. $\mathrm{H}_{2} \mathrm{O}$; cuvet 5: $2500 \mu \mathrm{l} \mathrm{rs}+$ $200 \mu$ l Monitrol I; cuvet 6: $2500 \mu \mathrm{l}$ bs $+200 \mu \mathrm{l}$ Monitrol $I$. The reaction was started by adding the sample as indicated by the arrow.

timing. This can easily be achieved by using an analyzer which transfers the prepared samples to the photometer in the same time sequence as it starts the reaction.

\section{Precision}

The precision of the mechanized procedure is summarized in table 1. The requirements of the College of American Pathologists (precision from day to day: cocoefficient of variation $<4.6 \%$ ) and the Guidelines of the Bundesärztekammer for Statistical Quality Control and Collaborative Surveys (precision from day to day: coefficent of variation $<10 \%)$ have been satisfied $(9,10)$.

\section{Accuracy}

The detection limit calculated according to Kaiser (8) is $18 \mu \mathrm{mol} / 1$. The calibration curve is nearly linear up to a concentration of $1500 \mu \mathrm{mol} / 1$ (fig. 4). A sufficient correlation was found when the uric acid concentration of

Tab. 1. The precision of the enzymatic determination of uric acid with the $C 4$ analyzer.

\begin{tabular}{|c|c|c|c|c|c|c|}
\hline Sample & $\begin{array}{l}\text { Precision } \\
\text { within ser } \\
\bar{x} \\
{[\mu \mathrm{mol} / 1]}\end{array}$ & $\begin{array}{l}\text { ries } \\
\mathrm{s}(\mathrm{n})\end{array}$ & $\begin{array}{l}\mathrm{CV} \\
{[\%]}\end{array}$ & $\begin{array}{l}\text { Precision } \\
\text { from day } \\
\overline{\mathbf{x}} \\
{[\mu \mathrm{mol} / \mathrm{l}]}\end{array}$ & $\begin{array}{l}\text { r-to-dąy } \\
\text { s (n) }\end{array}$ & $\begin{array}{l}\text { CV } \\
{[\%]}\end{array}$ \\
\hline $\begin{array}{l}\text { Standạad } \\
\text { solution }\end{array}$ & $\begin{array}{r}52.8 \\
101.7 \\
206.5 \\
501.0 \\
989.8\end{array}$ & $\begin{array}{l}1.7(20) \\
1.3(20) \\
1.6(20) \\
2.1(20) \\
3.9(20)\end{array}$ & $\begin{array}{l}3.2 \\
1.3 \\
0.8 \\
0.4 \\
0.4\end{array}$ & & & \\
\hline $\begin{array}{l}\text { Moni- } \\
\text { trol I }\end{array}$ & 465.0 & $5.2(19)$ & 1.1 & 465.0 & $9.1(19)$ & 2.0 \\
\hline $\begin{array}{l}\text { Sero- } \\
\text { norm }\end{array}$ & 391.9 & $3.3(10)$ & 0.8 & 391.9 & $7.2(10)$ & 1.8 \\
\hline
\end{tabular}



Fig. 4. Calibration curve of the uric acid determination according to Kageyama (1) Each point represents the mean of 5 values.

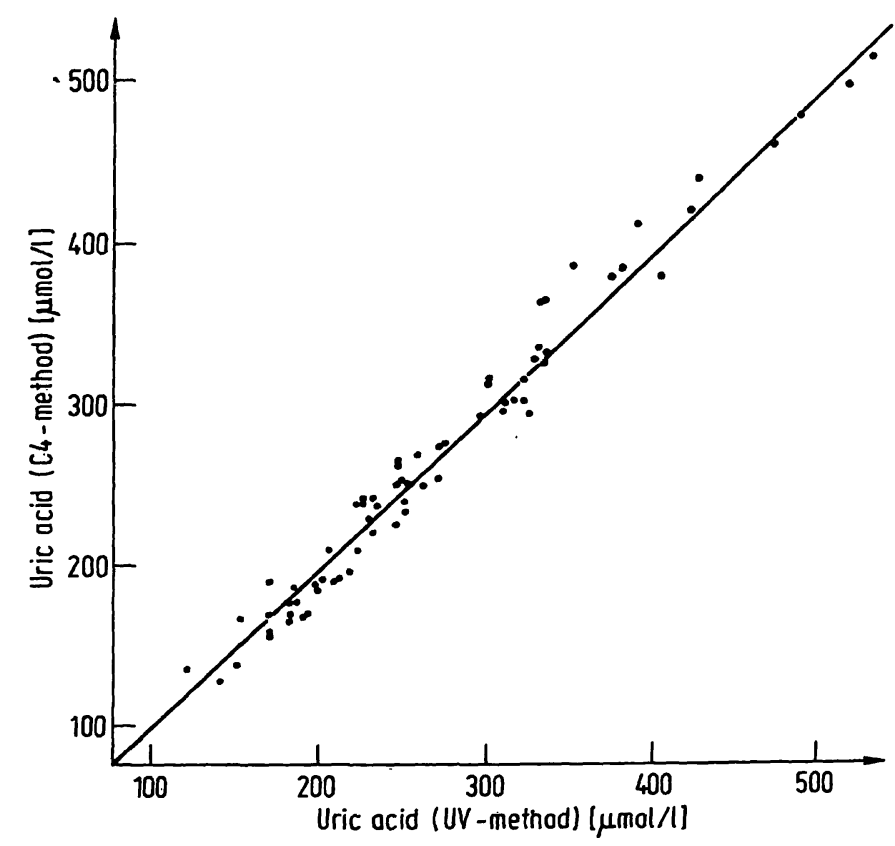

Fig. 5. The correlation of the uric acid concentration in serum samples from 70 patients determined according to Kageyama (1) and with an UV-method: $y=0.99 x+0.56$ $(r=0.99)$.

serum and urine samples from several patients were determined with this and with a direct UV-method (fig. 5 and 6). Recovery studies with pooled urine and serum samples are summarized in table 2 . For recovery studies it appeared necessary to add albumin to the standard solution $(70 \mathrm{~g} / \mathrm{l})$. Otherwise approximately $96 \%$ of the uric acid added were recovered (tab. 2). This effect was influenced by the protein (tab. 3 ) and the uric acid concentration (tab. 4); it was more pronounced with the UV- 


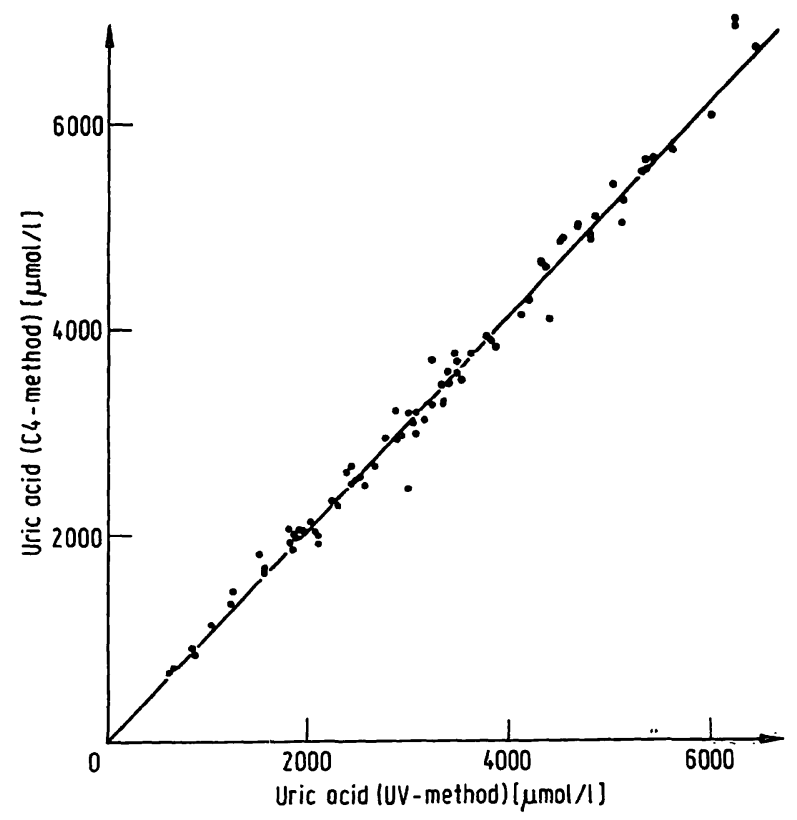

Fig. 6. The correlation of the uric acid concentration in urine samples from 80 patients determined according to Kageyama (1) and with an UV-method: $y=1.03 x+5.5 .9$ $(\mathrm{r}=0.99), \mathrm{n}=79$.

Tab. 2. Recovery of uric acid added to various human serum and urine samples. Each value $(\mu \mathrm{mol} / \mathrm{l})$ is a mean of at least 2 determinations.

\begin{tabular}{llll}
\hline Sample & $\begin{array}{l}\text { Uric acid } \\
\text { added } \\
{[\mu \mathrm{mol} / 1]}\end{array}$ & $\begin{array}{l}\text { found } \\
{[\mu \mathrm{mol} / 1]}\end{array}$ & $\begin{array}{l}\text { Recovery } \\
{[\%]}\end{array}$ \\
\hline
\end{tabular}

A) Calibration with a standard solution containing $70 \mathrm{~g} / 1$ albumin

$\begin{array}{lllr}\text { Serum } & 500 & 499 & 99.8 \\ \text { Serum } & 314 & 313 & 99.7 \\ \text { Serum } & 291 & 291 & 100.0 \\ \text { Serum } & 321 & 320 & 99.7 \\ \text { Serum } & 493 & 490 & 99.4\end{array}$

B) Calibration with a protein-free standard solution

$\begin{array}{llll}\text { Urine } & 489 & 489 & 100.0 \\ \text { Urine } & 488 & 492 & 100.8 \\ \text { Urine } & 510 & 500 & 99.8 \\ \text { Serum } & 469 & 431 & 91.9 \\ \text { Serum } & 467 & 442 & 94.6 \\ \text { Serum } & 298 & 270 & 90.6 \\ \text { Serum } & 294 & 286 & 97.3 \\ \text { Serum } & 544 & 520 & 95.6 \\ \text { Serum } & 540 & 521 & 96.5 \\ \text { Serum } & 547 & 529 & 96.7 \\ \text { Serum } & 280 & 272 & 97.1 \\ \text { Serum } & 508 & 472 & 94.1 \\ \text { Serum } & 512 & 480 & 93.7 \\ \text { Pooled Serum } & 497 & 480 & 96.6^{\mathrm{a}} \text { ) } \\ \text { albumin solution } & 500 & 482 & 96.4^{\mathrm{b}} \text { ) } \\ \text { (70 g/l) } & & & \end{array}$

a) mean value from various experiments at 12 days b) $n=2$.
Tab. 3. The influence of albumin on the uric acid concentration. Purified human albumin was added to a primary standard solution of uric acid $(500 \mu \mathrm{mol} / \mathrm{l})$. Each value $(\mu \mathrm{mol} / \mathrm{l})$ is a mean of 4 determinations.

\begin{tabular}{|c|c|c|c|}
\hline \multirow{3}{*}{$\begin{array}{l}\text { Albumin } \\
\text { concen- } \\
\text { tration } \\
\mathrm{g} / 1\end{array}$} & \multirow{3}{*}{$\begin{array}{l}\text { UV-method } \\
\text { Zeiss } \\
\text { photometer } \\
\text { PM 4 } \\
\text { Uric acid ( } \mu \text { mol }\end{array}$} & \multicolumn{2}{|c|}{ Kageyama procedure } \\
\hline & & C4 analyzer & $\begin{array}{l}\text { Eppendorf } \\
\text { photometer } \\
1101\end{array}$ \\
\hline & & & (Uricaquant) \\
\hline 0 & 500 & 500 & 502 \\
\hline 27 & 485 & 498 & - \\
\hline 63 & 456 & 490 & 488 \\
\hline 126 & 412 & 478 & 465 \\
\hline
\end{tabular}

Tab. 4. The recovery of uric acid from aqueous solutions containing bovine albumin $(135 \mathrm{~g} / \mathrm{l})$ in relation to the uric acid concentration. Each value $(\mu \mathrm{mol} / \mathrm{l})$ is a mean of 3 determinations.

\begin{tabular}{|c|c|c|}
\hline $\begin{array}{l}\text { Uric acid conc } \\
\text { with albumin } \\
{[\mu \mathrm{mol} / \mathrm{l}]}\end{array}$ & $\begin{array}{l}\text { n (C4 analyzer) } \\
\text { without albumin } \\
{[\mu \mathrm{mol} / \mathrm{l}]}\end{array}$ & $\begin{array}{l}\text { \% of control } \\
\text { (in the absence } \\
\text { of albumin) }\end{array}$ \\
\hline $\begin{array}{r}53 \\
108 \\
510 \\
999\end{array}$ & $\begin{array}{r}42 \\
93 \\
476 \\
943\end{array}$ & $\begin{array}{l}79 \\
86 \\
93 \\
94\end{array}$ \\
\hline
\end{tabular}

method (tab. 3) and can probably be explained by the urate binding capacity of albumin and other serum proteins $(11,12,13)$. When primary standard solutions are used for the calibration the results only correspond to the unbound part of the total uric acid concentration in serum.

With uricaquant, a commercially available test combination for the Kageyama procedure, the same results were obtained if the test was performed either with a C4 analyzer or manually following the instructions of the manufacturer (tab. 3).

Serum samples can be stored in a refrigerator $\left(+4^{\circ} \mathrm{C}\right)$ for at least one week. During this time the uric acid concentration is fairly stable (tab. 5).

Tab. 5. The stability of uric acid in human sera and urines if stored at $4^{\circ} \mathrm{C}$

\begin{tabular}{rccccc}
\hline Storage, days & 0 & \multicolumn{5}{c}{$\begin{array}{c}2 \\
\text { Uric aciad }[\mu \mathrm{mol} / \mathrm{l}]\end{array}$} \\
\hline Serum No. 1 & 368 & 370 & 370 & 365 & 369 \\
2 & 373 & 387 & 377 & 379 & 378 \\
3 & 341 & 347 & 345 & 339 & 340 \\
4 & 315 & 326 & 313 & 319 & 322 \\
$\frac{4}{\mathrm{x}}$ & 349 & 358 & 351 & 351 & 352 \\
& & \multicolumn{5}{c}{ Urịc acid [mmol/1] } \\
Urine No. 1 & 3.5 & 3.6 & 3.5 & 3.5 & 3.5 \\
2 & 4.4 & 4.6 & 4.6 & 4.5 & 4.6 \\
3 & 4.7 & 4.4 & 4.6 & 4.5 & 4.6 \\
4 & 1.1 & 1.2 & 1.2 & 1.2 & 1.2 \\
$\bar{x}$ & 3.43 & 3.45 & 3.48 & 3.43 & 3.48
\end{tabular}

Each value is the mean of 2 determinations 


\section{Drift effects}

As recently pointed out (2) drift- and interaction effects must be carefully investigated with fully mechanized analytical methods. Baseline- and sensitivity drift (2) between 20 samples were determined in segment $A$ and $\mathrm{C}$ (Fig. 2) of several batches on different days. The sensitivity drift was less than $1 \%$ (tab. 6), if measured with a concentration from the middle of the linear part of the calibration curve (2). The baseline drift need not be observed in every batch because it has the same value as the sensitivity drift (tab. 6).

Tab. 6. Drift effects in segment A and C ( 1 intersegment $B$ ). The numbers are means $(\mu \mathrm{mol} / \mathrm{l})$ from several determinations on different days. The calculation of the daily value occurred as shown in Fig. 2. The sensitivity drift was investigated with a standard containing $500 \mu \mathrm{mol} / 1$ uric acid, the baseline drift with bidist. $\mathrm{H}_{2} \mathrm{O}$.

\begin{tabular}{lll}
\hline Segment & A & C \\
\hline Baseline drift & $|2.7|(n=17)$ & $|2.7|(n=17)$ \\
Sensitivity drift & $|2.8|(n=19)$ & $|2.9|(n=14)$ \\
\hline
\end{tabular}

\section{Interaction effects}

From a theoretical standpoint 2 types of interaction are possible with the $\mathrm{C} 4$ Automatic Analyzer. A cyclic interaction (2) could not be detected when investigated according to the recently reported method for the determination of chloride (7), using a solution with 2000 $\mu \mathrm{mol} / \mathrm{l}$ uric acid and $7 \mathrm{~g} / 100 \mathrm{ml}$ purified albumin. The interaction from sample-to-sample was considerable and more pronounced in the presence bf protein (tab. 7). The addition of Brij-35 reduced the carry-over significantly (tab. 7).

Several procedures have been proposed (2) for the correction of all results by means of an interaction coefficient determined at the beginning of each batch from a series of 3-4 interaction standards. The coefficient of interaction varies considerably, even if determined serially (tab. 7). Therefore, a mean value of several determinations is preferable for the correction of all batch results.

It is common practice to neglect carry-over effects if the data cannot be processed by a computer. Since the interaction from sample-to-sample of the mechanized procedure was considerable (tab. 7), it was necessary to determine whether the effect on the results was sufficient to warrant correction. For this purpose, we postulate that the difference between the true and the observed value shall be lower than the 3 fold standard deviation of the corresponding mean value from several intrabatch determinations (tab. 1). Then, in extreme cases the result can differ approx. $3 \%$ from its true value in the normal range of the human serum concentration. Using a procedure recently described (7) the concentration range, in which interaction effects can be tolerated, was calculated (fig. 7). The analysis of a sample must be repeated if the preceding value is outside the so called interactionsafe range (fig. 7) or higher than $1000 \mu \mathrm{mol} / 1$.
Tab. 7. The interaction from sample to sample in the enzymatic determination of uric acid with the $\mathrm{C} 4$ analyzer.

\begin{tabular}{|c|c|c|}
\hline $\begin{array}{l}\text { Protein content } \\
\text { of the sample }\end{array}$ & $\frac{Q_{1}}{x}(\%), s(n)$ & $\frac{Q_{2}}{x}(\%), s(n)$ \\
\hline $\begin{array}{l}\text { no protein } \\
\text { (variation within } \\
\text { series) }\end{array}$ & $2.4 \pm 0.4(10)$ & $2.5 \pm 0.4(10)$ \\
\hline $\begin{array}{l}\text { no protein } \\
\text { (variation } \\
\text { from-day-to-day) }\end{array}$ & $2.4 \pm 1.0(18)$ & $2.5 \pm 1.0(18)$ \\
\hline $\begin{array}{l}\text { albumin } 70 \mathrm{~g} / 1 \\
\text { (variation from } \\
\text { day-to-day }\end{array}$ & $3.8 \pm 1.3(12)$ & $4.5 \pm 1.7(12)$ \\
\hline $\begin{array}{l}\text { albumin }(70 \mathrm{~g} / \mathrm{l}) \\
\text { and Brij } 35(1 \mathrm{ml} / \mathrm{l}) \\
\text { (variation from } \\
\text { day-to-day) }\end{array}$ & $2.5 \pm 0.4(15)$ & $2.4 \pm 0.4(15)$ \\
\hline
\end{tabular}

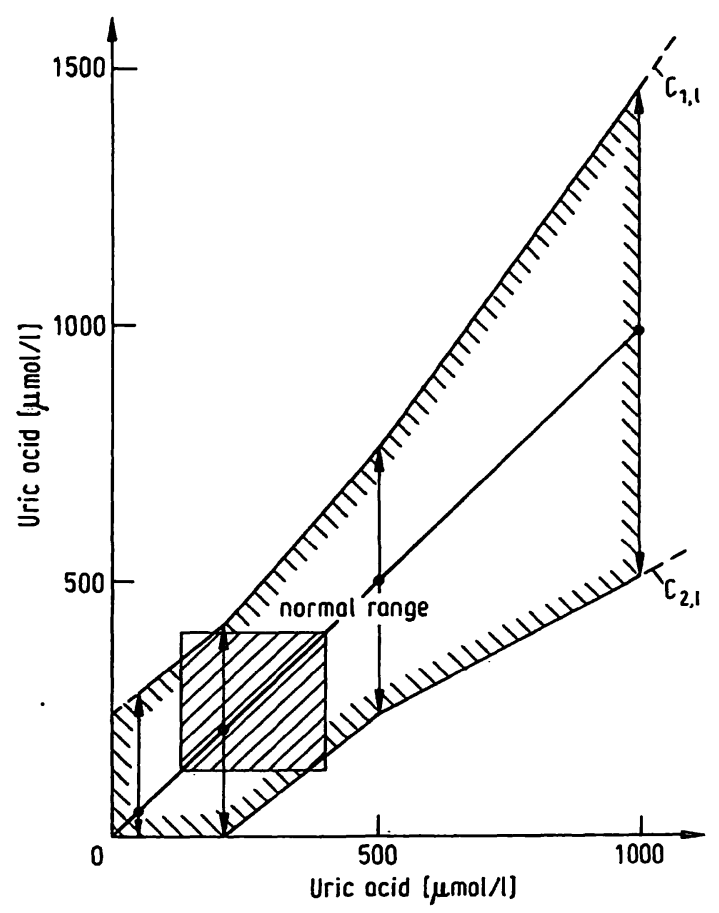

Fig. 7. Concentration range in which interaction effects can be tolerated with the C4 Automatic Analyzer.

The concentrations forming the interaction-safe range are calculated according to (7): $\mathrm{Cl}, \mathrm{l}$ for the interaction from low to high concentrations and $C 2, l$ for the interaction from high to low concentrations. The standard deviations are taken from table.1, the $Q$ values from table 4 (last line).

Tab. 8. The influence of ascorbate and bilirubin on the determination of the uric acid concentration according to Kageyama (1).

\begin{tabular}{llcc}
\hline Substance & $\begin{array}{l}\text { Uric acid } \\
\text { added } \\
\left.[\mu \mathrm{mol} / 1]^{1}\right)\end{array}$ & found & $\begin{array}{l}\text { Recovery } \\
{[\%]}\end{array}$ \\
\hline $\begin{array}{l}\text { Na-ascorbate } \\
0.5 \mathrm{~g} / 1\end{array}$ & 500.5 & 499.0 & 99.7 \\
$\begin{array}{l}\text { Na-ascorbate } \\
1.0 \mathrm{~g} / \mathrm{l}\end{array}$ & 500.5 & 496.5 & 99.2 \\
\begin{tabular}{l} 
Bilirubin \\
\hline
\end{tabular} & 500.5 & 502.0 & 100.3 \\
\hline
\end{tabular}

1) mean value of 2 determinations 


\section{Interferences}

Interference from bilirubin, triglycerides and ascorbate can be neglected with the determination of uric acid according to Kageyama (1) under the present conditions (tab. 8). Further studies were undertaken with a series of drugs representing the most common therapeutics used in human medicine (tab. 9). This list, in which the trade name mentioned may be considered as an example for all other drugs containing the same substance, was recommended by Staehler et al. (14). All substances were added in $10 \mathrm{ml} 9 \mathrm{~g} / \mathrm{l} \mathrm{NaCl}$ to $40 \mathrm{ml}$ of the same poolserum. These samples were analyzed in various series together with several control samples $(10 \mathrm{ml} 9 \mathrm{~g} / \mathrm{l} \mathrm{NaCl}$ $+40 \mathrm{ml}$ pool-serum). In the presence of tetracyclinum and methyldopum the uric acid concentration was determined slightly below the 2s-range (tab. 8); this effect could not be confirmed in further experiments". Novaminsulfone was the only substance which caused a consistent underestimation of the uric acid concentration (tab. 10). The oral intake of $6 \mathrm{mg} / \mathrm{kg}$ novaminsulfone $(1 / 8$ of the maximal dosage per day) leads to a serum concentration of $14 \mathrm{mg} / \mathrm{l}(16)$.

Tab. 9. Recovery of uric acid in human pooled sera containing various drugs. In the absence of any substance added a mean value of $239 \mu \mathrm{mol} / 1$ uric acid was found $(n=43$, $s=10.91,2 s-$ range $=217-261)$.

\begin{tabular}{|c|c|c|c|}
\hline Trade name & I. N. N. ${ }^{a}$ ) & $\begin{array}{l}\text { concen- } \\
\text { tration } \\
{[\mathrm{mg} / \mathrm{l}]}\end{array}$ & $\begin{array}{l}\text { uric acid } \\
{[\mu \mathrm{mol} / \mathrm{l}]}\end{array}$ \\
\hline Glifanan & glafeninum & 240 & 222 \\
\hline Aspirin & acidum acetylosalicylicum & 600 & 243 \\
\hline Butazolidin & phenylbutazonum & 120 & 250 \\
\hline Novalgin & novaminsulfonum & 800 & $\left.140^{b}\right)$ \\
\hline Buscopan & hyoscin-N-butylbrominum & 12 & 243 \\
\hline Amuno & indometacinum & 30 & 221 \\
\hline Dolviran & $\begin{array}{l}\text { acidum acetylosalicyli- } \\
\text { cum, etc. }\end{array}$ & 480 & 251 \\
\hline Prolixan 300 & azopropazon-dihydrat & 360 & 241 \\
\hline Actol & acidum nifluminicum & 150 & 232 \\
\hline Tanderil & oxyphenbutazonum & 120 & 257 \\
\hline Metalcaptase & $D$-penicillaminum & 480 & 234 \\
\hline Zyloric & allopurinolum & 80 & 251 \\
\hline Uricovac & benzbromaronum & 20 & 259 \\
\hline Benemid & probenecidum & 200 & 230 \\
\hline Lanicor & digoxinum & 0.15 & 217 \\
\hline Intensain & carbocromenum & & 237 \\
\hline Novadral & norfenefrinum & & 245 \\
\hline Miroton & glycosides, etc. & $6 \mathrm{ml} / 1$ & 248 \\
\hline $\begin{array}{l}\text { Aldaktone } \\
\text { Sembrina }\end{array}$ & spirolactonum & 20 & 222 \\
\hline $\begin{array}{l}\text { Sembrina } \\
\text { Modenol }\end{array}$ & $\begin{array}{l}\alpha \text {-methyldopum } \\
\text { thiabutazide, etc. }\end{array}$ & $\begin{array}{l}320 \\
2.6\end{array}$ & $\begin{array}{l}\left.208^{\mathrm{b}}\right) \\
254\end{array}$ \\
\hline Dipar & phenylethylbiguanide & 30 & 238 \\
\hline Euglycon & glibenclamidum & 3 & 234 \\
\hline Rastinon & tolbutamidum & 400 & 240 \\
\hline Solu-Decortin & prednisolonum & 200 & 233 \\
\hline $\begin{array}{l}\text { Aponal } \\
\text { Librium }\end{array}$ & $\begin{array}{l}\text { doxepinum } \\
\text { chlordiazepoxidum }\end{array}$ & $\begin{array}{l}30 \\
20\end{array}$ & $\begin{array}{l}228 \\
228\end{array}$ \\
\hline
\end{tabular}

\begin{tabular}{|c|c|c|c|}
\hline Trade name & I. N. N. ${ }^{a}$ ) & $\begin{array}{l}\text { concen- } \\
\text { tration } \\
{[\mathrm{mg} / 1]}\end{array}$ & $\begin{array}{l}\text { uric acid } \\
{[\mu \mathrm{mol} / 1]}\end{array}$ \\
\hline Methotrexat & $\begin{array}{l}\text { acidum methylpteroyl- } \\
\text { glutaminicum }\end{array}$ & 1 & 237 \\
\hline Endoxan & cyclophosphamidum & 40 & 227 \\
\hline $\begin{array}{l}\text { Megaphen } \\
\text { Luminal }\end{array}$ & $\begin{array}{l}\text { phenothiazinum } \\
\text { acidum phenylaethylbarbi- } \\
\text { tưricum }\end{array}$ & $\begin{array}{l}30 \\
80\end{array}$ & $\begin{array}{l}217 \\
220\end{array}$ \\
\hline $\begin{array}{l}\text { Hostacyclin } \\
\text { Paraxin } \\
\text { Binotal } \\
\text { Sulfa- . } \\
\text { Furadantin }\end{array}$ & $\begin{array}{l}\text { tetracyclinum } \\
\text { chloramphenicolum } \\
\text { aminobenzylpenicillinum } \\
\text { sulfametum }\end{array}$ & $\begin{array}{l}200 \\
600 \\
600 \\
300\end{array}$ & $\begin{array}{l}212^{\mathrm{b}} \text { ) } \\
\left.217^{\mathrm{b}}\right) \\
240 \\
237\end{array}$ \\
\hline $\begin{array}{l}\text { Furadantin } \\
\text { Durenat } \\
\text { Refobacin }\end{array}$ & $\begin{array}{l}\text { nitrofurantoinum } \\
\text { sulfanilamidopyrimidinum } \\
\text { gentamycinum }\end{array}$ & $\begin{array}{r}30 \\
200 \\
6\end{array}$ & $\begin{array}{l}229 \\
236 \\
242\end{array}$ \\
\hline Lasịx & furosemidum & 20 & 221 \\
\hline Dulcolax & bisacodylum & 4 & 244 \\
\hline $\begin{array}{l}\text { Angiografin } \\
\text { Urografin } \\
\text { Biligrafin }\end{array}$ & $\begin{array}{l}\text { acidum trijodbenzoicum } \\
\text { acidum trijodbenzoicum } \\
\text { adipinyltrijodanilidum }\end{array}$ & $\begin{array}{l}4 \mathrm{ml} / 1 \\
4 \mathrm{ml} / 1 \\
4 \mathrm{ml} / 1\end{array}$ & $\begin{array}{l}1253 \\
1246 \\
1223\end{array}$ \\
\hline Resochin & chloroquinum & 100 & 243 \\
\hline $\begin{array}{l}\text { Polybion } \\
\text { Nicobion }\end{array}$ & $\begin{array}{l}\text { vitamine B complex } \\
\text { nicotinamidum }\end{array}$ & $\begin{array}{l}0.8 \mathrm{ml} / 1 \\
40\end{array}$ & $\begin{array}{r}1241 \\
246\end{array}$ \\
\hline Cebion & acidum ascorbicum & 400 & 229 \\
\hline Marcumar & phenprocoumonum & 6 & 236 \\
\hline $\begin{array}{l}\text { Macrodex } \\
\text { Neoplasmagel }\end{array}$ & $\begin{array}{l}\text { dextranum } 6 \% \\
\text { gelatine } 6 \%\end{array}$ & $\begin{array}{l}100 \mathrm{ml} / \mathrm{l} \\
100 \mathrm{ml} / \mathrm{l}\end{array}$ & $\begin{array}{l}246 \\
247\end{array}$ \\
\hline Anticoagulantia & $\begin{array}{l}\text { Na-oxalate } \\
\text { Na-fluoride } \\
\text { Titriplex III } \\
\text { Na-heparinat } \\
\text { Na-citrate }\end{array}$ & $\begin{array}{r}3000 \\
2000 \\
1000 \\
750 \\
5000\end{array}$ & $\begin{array}{l}251 \\
256 \\
253 \\
248 \\
238\end{array}$ \\
\hline Dura-Clofibrat & clofibratum & 400 & 217 \\
\hline Antistin & antazolinum & 160 & 234 \\
\hline
\end{tabular}

Tab. 10. The effect of novaminsulfone on the uric acid concentration determined according to Kageyama in aqueous solutions.

\begin{tabular}{lll}
\hline novaminsulfone & $\begin{array}{l}\left.\text { uric acid }{ }^{2}\right) \\
{[\mathrm{mg} / \mathrm{l}]}\end{array}$ & $\begin{array}{l}\text { \% of control } \\
\text { (in the absence of } \\
\text { novaminsulfone) }\end{array}$ \\
\hline
\end{tabular}

A) aqueous solutions

\begin{tabular}{|c|c|c|}
\hline $\begin{array}{r}0 \\
10 \\
20 \\
100 \\
800\end{array}$ & $\cdots$ & $\begin{array}{l}500 \\
491 \\
482 \\
431 \\
352\end{array}$ \\
\hline
\end{tabular}

B) pooled sẹrum

\begin{tabular}{rrr}
0 & 388 & - \\
400 & 255 & 66 \\
800 & 229 & 59 \\
\hline
\end{tabular}

a) mean values of 2 determinations 


\section{Literature}

1. Kageyama, K. (1971). Clin. Chim. Acta 31, 421-426.

2. Haeckel, R. (1972), this j. 10, 235-242.

3. Praetorius, E. \& Poulsen, H. (1953). Scand, J. Clin. Lab. Invest. 5, 273-280.

4. Kortüm, M. \& Kling, O. (1972). Ärztl. Lab. 18, 33-36.

5. Liddle, L., Seegmiller, J. E. \& Laster, L. (1959). J. Lab. Clin. Med. 54, 903-913.

6. Praetorius, E. (1949). Scand. J. Clin. Lab. Invest. 1, 222-230.

7. Haeckel, R. \& Porth, A. J. (1972), this j. 10, 91-94.

8. Kaiser, H. (1965). Z. analyt. Chem. 209, 1-18.

9. Ausführungsbestimmungen und Erläuterungen zu den Richtlinien der Bundesärztekammer zur Durchführung der statistischen Qualitätskontrolle und von Ringversuchen im Bereich der Heilkunde. English translation: Dt. Ges. f. Klin. Chem. e.V. - Mitteilungen (1974) 2, 33-43.
10. Haeckel, R. (1975). Qualitätssicherung im medizinischen Laboratorium, Deutscher Ärzteverlag, Köln, 1-237.

11. Alvsaker, J. O. (1966), Scand. J. Clin. Lab. Invest. 18, 227-239.

12. Klinenberg, J. R. \& Kippen, I. (1970). J. Lab. Clin. Med. 75, 503-510.

13. Sheikh, M. I. \& Möller, J. V. (1968). Biochem. Biophys. Acta 158, 456-458.

14. Staehler, F., Munz, E. \& Kattermann, R. (1975), Deut. Med. Wochenschr. 100, 876-887.

15. Lexikon chemischer Kurzbezeichnungen von Arzneistoffen (1968), Govi Verlag GmbH, Frankfurt, 1-423.

16. Christ, O., Kellner, H. M., Ross, G., Rupp, W. \& Schwarz, A. (1963). Drug Res. 23, 1760-1767.

Prof. Dr. R. Haeckel

D-3300 Hannover 61

Karl-Wiechert-Allee 9 
.

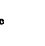

